\title{
Kä-Ki-Ku-oppismistyyli yhdistää kielen ja kulttuurin opetuksen
}

\section{EEVA-MAIJA LAPPALAINEN}

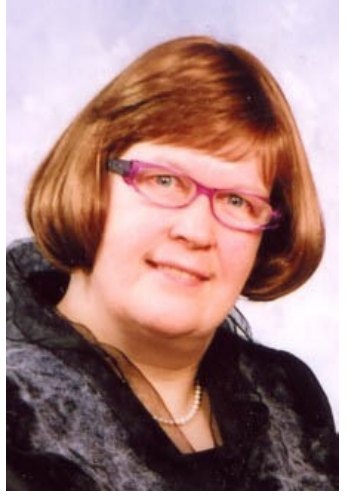

Käsityön, kielen ja kulttuurin oppimisen yhdistäminen on harvinaista. Se tarkoittaa sitä, että opetuksen käytännöissä pedagogiikan sisältöalueeksi liitetään harkitun tietoisesti käsityön, kielen ja kulttuurin oppimista. Menetelmä maahanmuuttajien suomen kielen oppimiseksi syntyi käsityön, kielen ja kulttuurin oppimisprosessissa. Väitöstutkimukseni tuloksissa se nimeytyi Kä-Ki-Ku-oppimistyyliksi.

\begin{abstract}
Menetelmän (Lappalainen 2005) lähtökohta on kielen oppimisen kytkeminen käsityön oppimiseen. Se on myös pedagogiikan käytön ydin. Toiminnan reflektointiin osallistuvat opettaja ja opiskelijat tiedoillaan, taidoillaan, kaikilla aisteillaan ja sydämellään. Reflektion muotona kulttuurisesti sensitiivinen työskentely on moniaistista ja meditoivaa. Siten toteutuu kulttuurisesti sensitiivisellä otteella syvälle luotaava kulttuuritietoinen reflektio.

Menetelmän (Lappalainen 2005) lähtökohta on kielen oppimisen kytkeminen käsityön oppimiseen, se on myös pedagogiikan käytön ydin. Toiminnan reflektointiin osallistuvat opettaja ja opiskelijat tiedoillaan, taidoillaan, kaikilla aisteillaan ja sydämellään. Reflektion muotona kulttuurisesti sensitiivinen työskentely on moniaistista ja meditoivaa. Siten toteutuu kulttuurisesti sensitiivisellä otteella syvälle luotaava kulttuuritietoinen reflektio.
\end{abstract}

Kä-Ki-Ku-oppimistyyli poikkeaa tavanomaisesta tekemällä (learning by doing) oppimisesta. Siinä samoin kuin käsityön opiskelussa opetellaan työtekniikkaa ja tuotoksen valmistelua. (Ks. Dewey 1910/1960; 1913/1957; 1934/1987.) Menetelmän keskiössä on kielen ja käsityön oppimisen kannalta oppisisältöjen poiminta, erittely ja tulkinta.
Oppimistyyli on sukua myös kielikylvylle, suggestopedialle ja kontekstuaaliselle oppimiselle. Oppisisältöjä erittelevän ja meditatiivisesti syvälle luotaavan otteensa vuoksi Kä-Ki-Kuoppimistyyli on myös itsenäinen menetelmä. Aidonkaltaisten oppimis- ja toimintaympäristöjen luomisessa on yhtäläisyys kontekstuaaliseen oppimiseen. Kuitenkin tämä eroaa siitä kompleksisuutensa vuoksi (Ks. Poikela 1999/2004). Erot ilmenevät myös siinä, että käsityön oppiminen altistetaan tässä menetelmässä palvelemaan kielen oppimista. Kielen oppimisessa voidaan pitää tärkeänä oppisisältötietoisuutta, toiminnan autonomisuutta ja autenttisuutta. (Alanen 2000; van Lier 2004) Näin on myös Kä-Ki-Ku-oppimistyylin käytössä, mutta lisäksi siinä tarkastellaan analyyttisesti käsityön, kielen ja kulttuurin yhtymäkohtia ilmiöiden ja asioiden välisissä suhteissa. Opettaja voi hyödyntää kehittyneen materiaalin käyttötajun, työtapojen valinnan ja värien valinnan pedagogiikan sisältöosaamiseen. Konkreetit ilmiöt avaavat ja silloittavat tietä abstraktioille, joita kielen oppimisessa tarvitaan.

Suggestopedia on bulgarialaisen Lozanovin kehittämä menetelmä. Siinä painottuu turvallinen ja rentoutunut ilmapiiri. Tämä ominaisuus liittyy myös Kä-Ki-Ku-oppimistyyliin. Opetustapojen yhtäläisyys ilmenee siinä, kun opetettavaa 
asiaa aktivoidaan monin tavoin (Lozanov, 1978; Lappalainen 2005.) Jossain määrin Kä-Ki-Kuoppimistyyli vertautuu Kanadassa kehitettyyn kielikylpyyn (Peal ja Lambert 1962). Molemmissa suositaan kielen omaksumista luonnollisissa ja mielekkäissä kommunikaatiotilanteissa. Siten opiskelijoita rohkaistaan kielen aktiiviseen käyttöön.

Kun Kä-Ki-Ku-oppimistyylissä kielen ja kulttuurin oppiminen liitetään käsityön oppimiseen, maahanmuuttajan oppimisprosessi avartuu ja syvenee. Käsityöllisen toiminnan oppiminen ja kielen oppiminen peilautuvat opettajan ohjaamana yhteiskunnan ja maahanmuuttajien tarpeisiin. $\mathrm{Ne}$ lähtevät dialogista ja haasteesta helpottaa kielen ja kulttuurin oppimista. Myös työstettävä materiaali ihmisen käsissä asettaa tekijänsä vuorovaikutukseen. Käsityön kannalta vuorovaikutuksen purkamisen tärkeimpiin merkityksiin liittyy ihmisen ja materiaalin välisen yhteyden saavuttaminen. Päämääräksivoidaan asettaa käsityön oppijan (sekä) ekologisen (että) tai kulttuurisen tietoisuuden, käsityön laatua koskevan tietoisuuden herättäminen.

Lisäksi käsitysten vaihtoon tähtäävässä inhimillisessä toiminnassa materiaalien kosketustuntua ja -muistia voidaan hyödyntää apukielenä uuden kielen oppimisprosessissa. Siten käsityöllisen toiminnan oppimisessa myös väri- ja materiaali-ilmaisu tunto- ja kosketusaisteineen voidaan asettaa palvelemaan kielen oppimista. Siihen opettajan on ohjattava maahanmuuttajaa oman kulttuuritietoisuutensa avulla. Tällöin pelkkään työstämiseen uppoutumisen sijasta opitaan yhdessä poimimaan oppimiskontekstista kielen oppimisen kannalta mielekkäitä sanoja. Niitä tarkastellaan yhdessä, kun kielen rakenteita ja käyttöä harjoitellaan. On tärkeää, että käsityön ja kielen oppimisen syklejä säädellään, joten välillä käsityön tekeminen ja sen oppiminen keskeytyy. Opettaja ohjaa maahanmuuttajia soveltamaan omaa kielitietoaan. Näin ollen he oppivat suomen kieltä merkityksellisesti mekaanisen kielenoppimisen sijasta.

\section{Etno-opettajaksi kasvamisen vaiheikas polku}

Tutkimukseni kohteena oli pohjoiskarjalaisessa kunnassa vuonna 1994 pitämäni suomen kielen ja kulttuurin maahanmuuttajakurssi. Siellä opiskeli Bosnia-Hertsegovinasta, Somaliasta ja Venä- jältä kotoisin olevia maahanmuuttajia. He kaikki olivat kiintiöpakolaisia lukuun ottamatta Suomeen avioitunutta venäläistä naista. Kokosin tutkimusaineiston ääneen ajattelun menetelmällä meditatiivisesti. Työmatkoilla, autolla ajaessani, kuvailin ääninauhoille koulutuspäivästä mieleenpainuvimmat asiat. Käytin aineistona myös oppimateriaalimallinäytteitä, piirroksia ja valokuvia. Tutkimukseni oli toimintatutkimuksellinen tapaustutkimus. Analysoin tutkimusaineiston kontekstikohtaisella kuvailevalla sisällönanalyysillä. Kirjallisuuspohjaisessa tarkastelussa käytin myös abduktiivista päättelyä. (vrt. Syrjäläinen 1994, 90.) Näin alkoi hahmottua väitöskirjani Kulttuurisesti sensitiivinen opettajuus; Käden, kielen ja kulttuurin oppimisen yhdistäminen maahanmuuttajien koulutuksessa ja opettajan kasvupolulla (Lappalainen 2005.)

Väitöskirjani syntymisen juuret johtavat työskentelyyn kansanopistossa ja vaiherikkaaseen opettajan kasvupolkuun. Asuin ja työskentelin kymmenen vuotta elämästäni kansanopistomiljöössä. Siellä 1980-luvulla opiskelleet amerikansuomalaiset naiset ja miehet olivat kiinnostuneita kankaankudonnasta ja neulonnasta. He perehtyivät niiden tekemisen oppimiseen ensimmäistä kertaa elämässään. Nämä käsityömuodot olivat amerikkalaisille Suomen symboleja ja kulttuuritietoisuutta rakentavan kasvun osatekijöitä. Nämä käsityömuodot olivat myös kulttuuritietoisuuden tarkastelun, analysoinnin ja tulkinnan sisältöalueita. (Lappalainen 1999; 2001; 2005,168 .) Heidän parissaan työskentely edisti kulttuurien kohtauttamisessa käytettävän pedagogian ja kulttuurisesti sensitiivisen opettajuuden syntymistä. Tässä oli alkusysäys käden, kielen ja kulttuurin yhteyden tutkimiseen (Lappalainen 2001).

Useiden vuosien aikana saamani kokemukset kannustivat opetussuunnitelmallisiin ja -menetelmällisiin ratkaisuihin, jotka syntyivät konkreetin ja abstraktin kulttuuritietoisuuden yhdistämisestä. Käsitykseeni kieltä ja käsityötä käsittävästä kulttuuritietoisuudesta sisältyy tieto käytössä olevasta kulttuuriperinnöstä. (Ks. Padilla 1980.) Huolimatta esimerkiksi kohdemaan tai ryhmän kulttuurista käsityön tekemisen oppimisessa havaitaan lukematon määrä kulttuuriperustaa ilmentäviä yhtäläisyyksiä. Niitä muodostuu (maahanmuuttaja)opettajan ja -opiskelijoiden yhteisistä kulttuuriperinnön osatekijöistä, kuten käsityksestä kielen oppimisesta, yhteiskunnasta, 
vuorovaikutuksesta, tarkoituksesta ja tavoitteista. Kulttuuritietoisuus ilmenee ohjattuna pedagogisen sisältöosaamisen käytännöissä. Tällöin poimitaan yhtymäkohtia ts. analogioita ja assosiaatioita kulttuurin ja yhteiskunnan osista. Tässä vaikuttaa toiminnan kokonaisvaltaisuus, tiedollinen, toiminnallinen ja yhteiskunnallinen kulttuurien kohtauttamisen edistäminen.

Kielen oppimista palveleva käden, kielen ja kulttuurin yhdistämistä kuvaava väline kehittyi työskennellessäni kansan- ja kansalaisopistossa. Sen perustana on tiedon välittyminen kommunikaatiotilanteissa. Tätä kuvaava (monikulttuurisuus) pedagogiikka rakentuu kulttuurin, tiedon, toiminnan, kokemusten, elämäkerrallisuuden ja kulttuurien kohtaamiseen vaikuttavien havaintojen tekemisestä. Se ilmentyy herkkyytenä havainnoitaessa yhteiskunnallisia ilmiöitä, monikulttuurisuuspolitiikkaa tai käsityöllisen toiminnan monitieteistä perustaa .

\section{Käden taidon ja kielitiedon} tarkastelua, analysointia ja tulkintaa?

Moni pitää käsityön oppimista yksinomaan käden/kätevyyden oppimisena, sen harjoittamisena tai hallintana. Monet näkevät myös kielen pelkkänä lingvistiikkana. Sekä kieli että käsityö kuuluvat kulttuuriin ja kulttuuriperintöön (Ks. esim. Padilla 1980; Lappalainen 1999; 2001; 2003a-b; 2005). Se, minkälainen käsitys ihmisellä on käytössä olevasta kulttuuriperinnöstä ja sen osista, on kulttuuritietoisuutta. Käytännössä inmisen kulttuuritietoisuus ilmenee muun muassa kielen omaksumisessa. Se välittyy myös käsityön värien, materiaalien, käsityöllisen toiminnan muotokielen tuntemisena ja valintakäyttäytymisenä. Uusiin käyttöyhteyksiin soveltaminen toimii käsityöllisen toiminnan integrointina kielen oppimiseen. Kulttuuritietoisuus ilmenee sekä käsityötekniikoiden käytön että valmiiden käsitöiden analysointi- ja erittelykykynä. Vaikka kouluissa ja oppilaitoksissa kieli ja käsityö luokitellaankin kulttuuriaineiksi käsityön, kielen ja kulttuurin keskinäinen yhteys on hämärtynyt. (Lappalainen 1999; 2001; 2005.)

Opettaja voi hyödyntää opetukseen oman kulttuuriperintönsä, -tietoisuutensa ja -osaamisensa. Siihen kuuluu muun muassa käsitys kielestä ja sen oppimisesta sekä omasta että vieraasta kulttuurista. Kulttuuriperintöön ja -tietoisuuteen sisältyy myös käsitys ihmiskäden töiden synnystä ja niiden käytöstä. (Carneiro 1975). Nämä ovat hyödynnettävissä kulttuurien kohtaamisen edistämiseen. Kulttuurien kohtaamisessa on tärkeää pohtia kahta akkulturaatioteorian käsitettä: kulttuuritietoisuus ja etninen lojaalisuus. Kulttuuritietoisuus tarkoittaa sitä tietoa, joka inmisellä on käytössä olevasta kulttuuriperinnöstä. Etninen lojaalisuus tarkoittaa mieltymyksiä käytössä olevaa kulttuuriperintöä kohtaan. (Padilla 1980; Lappalainen 2001;2005.)

Nykyisin on alettu rakennella erilaisia projekteja kohti monikulttuurista käsityötä. Pääasiallisena tehtävänä näissä on ollut opettaa maahanmuuttajille käsityötä vieraalla kielellä. Tutkimuksessani on kysymys toisenlaisesta ilmiöstä. Siinä käsityön suunnittelu, toteutus, analysointi ja kulttuurin oppiminen altistetaan palvelemaan erilaisista taustoista tulevien maahanmuuttajien suomen kielen oppimista. Kielen oppimisen lisäksi on huolehdittu myös siitä, että työn tuloksena syntyneet tuotteet ja esineet ovat toimivia ja käyttökelpoisia. (Lappalainen 2005.) Vrt. kuva 1 ja 2.

\section{Etninen kulttuuriorientaatioprosessi}

Kulttuurien kohtauttamisen vaatimukset lisääntyvät, tahdoimmepa me sitä tai emme. Erilaisista kielellisistä ja kulttuurisista taustoista lähtöisin olevat maahanmuuttajat ovat osa yhä useampien oppilaitosten arkea. Kulttuurien kohtaaminen, sen edistäminen ja kulttuurien kohtauttaminen on opettajalle etninen kulttuuriorientaatioprosessi. (Lappalainen 2005.) Opettajuudelle, sen kehittymiselle ja rakentumiselle asetetaan erityisiä tehtäviä, odotuksia, vaatimuksia ja velvoitteita. Työssä tarvitaan myös luovuuden tunnistamista ja siten sen määrittelyä (Fisher 1990/1995). Voidaan pohtia, mikä opettajan työssä on erityistä muihin ammatteihin verrattuna: mikä erottaa opettajat muista kulttuurien kohtaajista.

\section{Valtakielen ja -kulttuurin oppiminen}

Vielä nykyisinkin maahanmuuttajat voivat yhtäältä uppoutua kielen opiskeluun, niin kuin ammattiin kouluttautumisen ja yhteiskunnassa asioimisen kieltä ei olisikaan. Toisaalta useille suomen kielen kursseille osallistuneet inmiset voivat kokea sen opiskelun hyvin ongelmallisena. Oppisisältöihin on saattanut kuulua mahdollisimman seikkaperäinen suomen kielen raken- 
teen ja kieliopin käsittely. Näitä kursseja käyneet maahanmuuttajat eivät ehkä rohkene käyttää kieltä yksinkertaisissakaan yhteyksissä. Maahanmuuttajat kulttuureineen saattavat marginalisoitua.

Kulttuuritietoisuutta kuvaavien yhtymäkohtien löytyminen maahanmuuttajan ja kohdemaan kulttuurista on tärkeää. Syrjäytymistä on vaikea välttää, jos (hyvässäkin tarkoituksessa) maahanmuuttajista ja heidän kulttuuristaan tehdään näytteille asetettuja "kulttuurimaskotteja" niin, että kulttuuri irrotetaan kontekstistaan, kun maahanmuuttajia ja heidän tekemisiään esitellään (Lappalainen 2005.)

\section{Oman vai vieraan kulttuurin käyttö?}

Kulttuurien kohtauttamiseen kuuluu kysymys, miten maahanmuuttajan omaa kulttuuria hyödyntävä ja rakentava vuorovaikutus voi toteutua vastaanottomaan kulttuurissa. Rakentavalle vuorovaikutukselle on luotava hyvät edellytykset maahanmuuttajien koulutuksessa ja kulttuurien kohtauttamisessa. Sen toteutumiseksi on kyettävä menemään maahanmuuttajia vastaan. Kulttuuriilmiötä on analysoitava pedagogisessa sisältöosaamisessa. Ehtona on pidettävä ennen muuta opettajan omaa kulttuurinsa tuntemusta ja kulttuuritietoisuutta sen eri osista.

Esimerkiksi käsityönopettajalla pitää olla syvällistä tietoa käytössä olevasta kulttuuriperinnöstä: käsityön (oppimisen) materiaaleista, työvälineistä ja värien käytöstä. Kulttuurien kohtauttamiseen opettaja tarvitsee näkemyksen ja hyvän kulttuuritietoisuuden kielestä, sen oppimisesta, yhteiskunnasta ja maahanmuuton hallinnoinnista. Maahanmuuttajien opettajan työ on toimenkuvaltaan kompleksista. Opettaja joutuu monien uusien ja outojen tehtävien eteen.

Kulttuurien kohtauttamisen risteyspaikoissa opettajan on oppimisympäristöissä otettava kantaa etnofilosofisiin, -psykologisiin, -sosiologisiin, -kulttuurisiin, -sosiaalisiin ja yhteiskuntapoliittisiin kysymyksiin. (Kuvat 2, 3, 4) Käsityöllinen toiminta yhdistyy myös taiteiden harjoittamiseen. Näistä lähtökohdista käsityöllisen toiminnan oppimista voidaan entistä laajemmin käyttää maahanmuuttajien koulutuksessa kielen oppimisenkin välineenä.

Kulttuuritietoisuuden erittelyssä on havaittava, minkälaisissa konteksteissa käsin tehtäviä tuotteita ja esineitä on toisessa kulttuurissa käy- tetty. Tarvitaan myös näkemystä siitä, minkälainen kulttuuriperinnön hyödyntäminen palvelee kulttuurien kohtauttamista. Siksi kulttuurisesti herkkä ote on tärkeä. Kulttuurien kohtaamisen ja kohtauttamisen edistämisessä voidaan etsiä ja löytää pienin yhteinen nimittäjä. Käsityön oppimista voidaan hyödyntää laajemmin ja kauaskantoisemmin kulttuurien kohtauttamiseen päin. Käsityö on aina sidoksissa kieleen. Joku voi tuoda näytille itsensä ja toisten tekemät tuotokset. Hän voi mutista, ettei niiden syntymisessä kieltä paljon tarvita. Kuitenkin Suomessa suomen kieli on läsnä kaikessa opetuksessa. Tuotamme ja toteutamme sen suomeksi. Tästä seuraa, että huolimatta opetusalasta jokainen opettaja on myös suomen kielen opettaja ja jokainen oppitunti on suomen kielen oppitunti.

Käsityön ja kielen oppimisen yhdistymisessä kulttuuritietoisuus ilmentyy muun muassa suurifrekvensiivisten ts. yleismerkityksisten sanojen käytössä. Tällöin poimitaan käsityön oppimisen etenemisen myötä muissakin elämänkonteksteissa käytettäviä sanoja. Niitä käytetään aktiivisesti ja eri käyttöyhteyksiä esitellään. Yhtymäkohtien havaitseminen ja käyttö käsityön kielestä yleiskieleen on kulttuuritietoisuuden kehittymisessä syntynyttä herkkyyttä. Se toimii siirryttäessä helpoista kielen käytön tilanteista vaikeampiin. Näin kieltä ja sen oppimista voi jatkuvasti liittää käsityön ja kulttuurin oppimiseen.

Kä-Ki-Ku-oppimistyyli näyttäytyy elämäkerrallisena, oppimis- ja kasvupolkuni prosesseissa syntyneenä metodisena työvälineenä. (Lappalainen 2001; 2003a-b; 2004a-b; 2005). Oppimistyyli määrittää myös identiteetin ja vuorovaikutuksen, mahdollistaa innovoivan toiminnan ja monien aistien käytön. Luettavaksi ja pohdittavaksi sopii käsityön moninaisuuden avautumista ajatellen Haavikon $(1984,14)$ T.S. Eliotin hengessä kirjoittama runo:

"Joku tulee täällä vanhaksi ja kulkee sokeana lammikon ympärillä.

Ihmettelee veden hiljaisuutta ja kaikkea vettä. Kuullaan aikakausien usein kuluvan iloisina, kysytään purkamisen jälkeen, millainen talo oli, ja oliko koskaan rakennettu." (Haavikko 1984, 14.)

Kulttuurien kohtauttajaksi ja esiammatillisuuteen kasvattajaksi

Suomeen on tullut ja tulee maahanmuuttajia, jot- 
ka mahdollisesti eivät elämänsä aiemmissa vaiheissa ole koskaan ajatelleet muuttavansa toiseen maahan tai opiskelevansa mitään vierasta kieltä. Vieraan kulttuurin ja asuinmaan kielen oppiminen on monimutkainen vuorovaikutusprosessi, jossa ovat mukana sekä muualta lähteneet että paikalliset kulttuuriryhmän jäsenet. On paljon esimerkkejä siitä, että useita kielikursseja käyneet maahanmuuttajat eivät ole kunnolla oppineet suomea. He eivät hallitse sosiaalisen kanssakäymisen kieltä eivätkäomassaammatissavaadittavaa kieltä. Heillä ei ole myöskään akateemisesti miellettävää kieltä eikä virastoasioimisen kieltä. Apua ongelmaan löytyi tutkimuksessani esiammatillisuuden käsitteestä ja sen käytännöistä. (Lappalainen 2005.) Esiammatillisuus tarkoittaa sitä, että ammatillisen oppimisen sisältöjä käytetään toisissa konteksteissa. Käsityöllistä toimintaa käytettiin ympäröivää yhteiskuntaa hyödyttäviin ja maahanmuuttajien oppimista edistäviin tarkoituksiin. Maahanmuuttajat osallistuivat muun muassa paikkakunnalla pidettäviin joulumyyjäisiin, ystäväpalvelutoimintaan ja moniin yhteistyömuotoihin.

PIIRRos 1. (Genre murtuu) Oppimisympäristöissämme syntyi käyttökelpoista virike-, havaintoja oppimateriaalia: Värit, muodot, mallit ja materiaalit ja niitä työstävät kehon liikkeet innostivat puhumaan suomen kielellä. Aihealueet olivat konkreetteja. Ohjattuina ne kannustivat kehittävään siirtovaikutukseen kielen oppimisessa. Pirta-ja lautanauhan nauhan kutomisen alkaessa käyttämämme tiukentaa, vaihtaa, vetää ja kiristää-verbit kertautuivat. Maahanmuuttajien kädet auttoivat vähän kerrassaan käsittämään suomen kieltä ja käytössä olevaa kulttuuria (Lappalainen 2005,128 ).

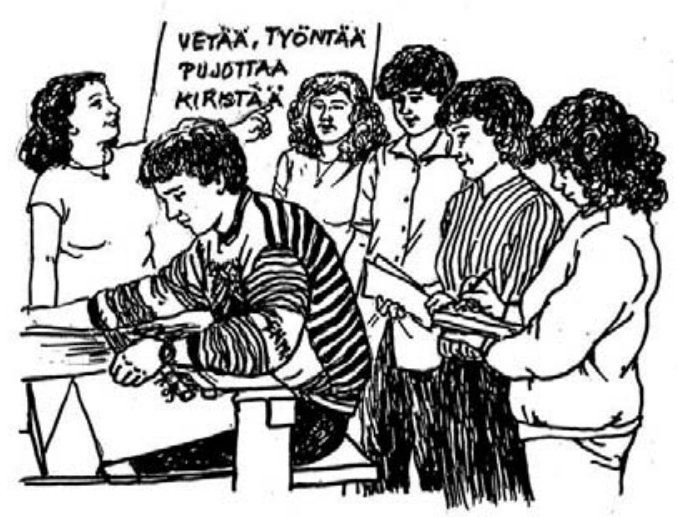

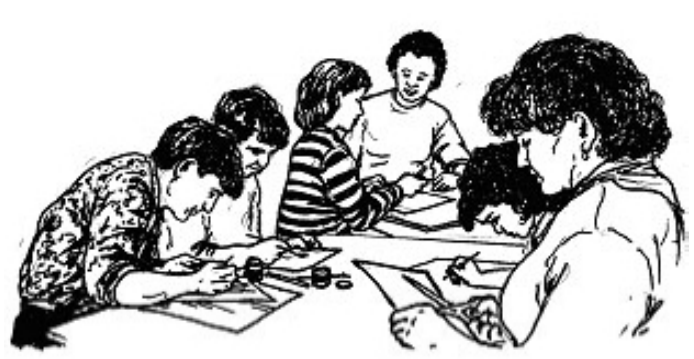

PIIrRos 2. (Ryhmä suunnittelee) Ryhmä pohti suomen kielellä ystävänpäivän ja YK:n päivän järjestämistä tai valmistautui myymään valmistamiaan tuotteita paikkakunnalla pidettävissä joulumyyjäisissä (Lappalainen 2005, 119).

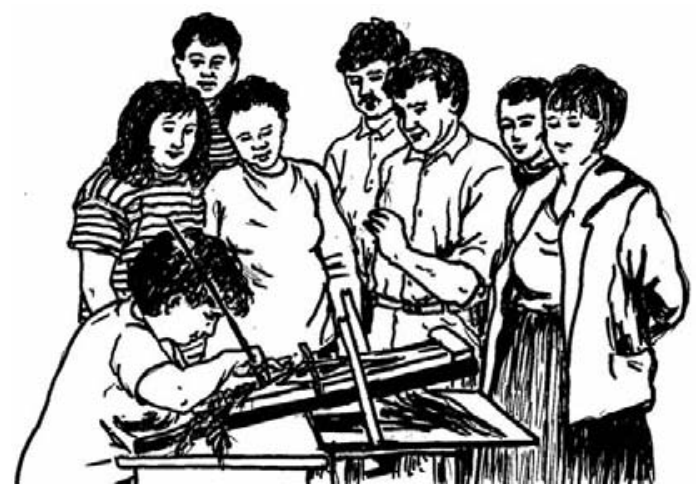

Piirros 3. (Kutoja ja katsojat) Nuorempi bosnialaismies toisti kankaankudonnan opiskelussa oppimiaan suomen kielen sanoja, joita myös naisten puhekuoro kertasi. Monien aistien avulla havainnollistuneet suomen kielen sanat suullistuivat maahanmuuttajaryhmässä. Ne kirjallistuivat fläppitaululle ja maahanmuuttajakurssilaisten muistiinpanoihin (Lappalainen 2005, 126).

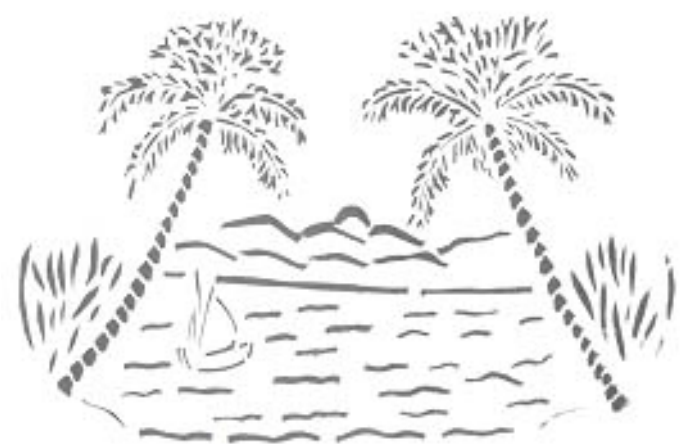

Kuva 1. ("Palmuranta") Peruskouluikäinen koulupoika piirtää taidokkaita kankaanpainantamalleja äidilleen ja leikkaa ne kotonaan. Niis- 
sä on sydämiä, kuvion sisällä enkeleitä, kukkia ja palmupuukeitaita. Yhdessä kuvassa on purjevene. Kokeilemme sarjatyötä, kun alamme työstää myyjäisiä varten pöytäliinoja. Mustanmeren vaikutteet näkyvät koulupojan piirtämässä kankaanpainantamallissa. Puhumme suomea ja painamme merta ja palmupuita (Lappalainen 2005, 150).

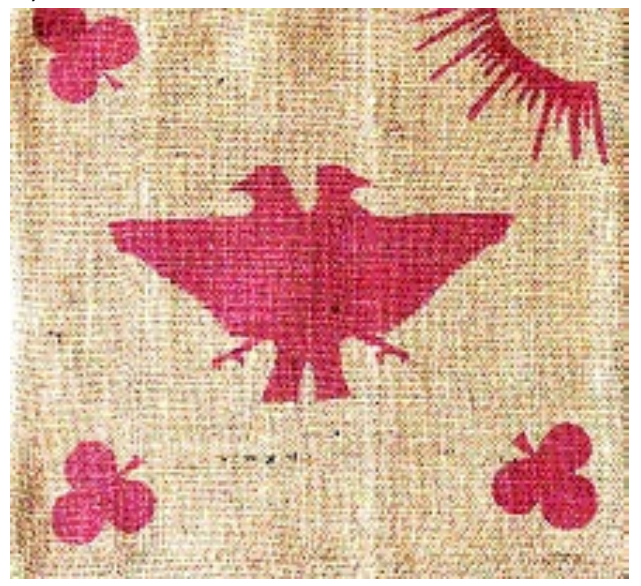

Kuva 2. (Kosovon lintu) Maahanmuuttajat kertoivat suomeksi, että Kosovon lintu on kaksipäinen lintu ja Kosovon onnen apila on kolmilehtinen. He piirsivät auringon ja osoittivat, että Kosovon aurinko paistaa täydeltä terältä, kun he pääsevät muuttamaan sinne takaisin (Lappalainen 2005, 109).

Traumaattiset kokemukset vaikuttavat kielen oppimiseen. Yleensä sanotaan, että lapset oppivat kielen nopeasti. Kuitenkin vaikeista kokemuksista kärsivät inmiset, niin lapset kuin aikuisetkin, jaksavat opiskella suomen kieltä tehokkaasti vain pari tuntia päivässä. Maahanmuuttajien koulupäivä on kuitenkin pitempi. On pohdittava, miten monikulttuurisuutta edistävä pedagogiikka auttaa toimimaan tarkoituksenmukaisesti kahden tunnin jälkeen? Käsityön, kielen ja kulttuurin oppimisen yhdistäminen auttoi maahanmuuttajien jaksamistai:

-Se on hyvä, että näkee samalla havainnollisesti, mitä sana tarkoittaa. Tekemisessä oppii paremmin, kuin jos opettaja puhuu ja kirjoittaa paljon taululle. On hyvä ajatella oppilaiden kuntoa. Kunto sälyi, kun me opimme kieltä ja käsityötä. Se auttoi paljon. Ei oppilas jaksa, jos on joka päivä viisi tai kahdeksan tuntia kielioppia. (Lappalainen 2005, 140.)

Kohtasin maahanmuuttajakurssilla BosniaHertsegovinasta, Somaliasta ja Venäjältä Suo- meen tulleita maahanmuuttajia. Heillä kaikilla oli keskenään erilaiset taustat ja elämänhistoriat. Tutkimukseni osoitti, että opettaja tarvitsee hyvän oman kulttuurin tuntemuksen, joka välittyy yhtymäkohtien, assosiaatioiden, analogioiden jne. havaitsemisena käsityössä, kielessä ja kulttuurissa. Tällöin kaukaisen ymmärtäminen tapahtuu läheisen välityksellä. (Lappalainen 2005, 168.)

\section{Tuppisuina vai puhumisvyöryn äärellä?}

Käsityönopettaja käyttää elämän ja elämäkertaisuuden ammattitaustaa. Tekemisen lisäksi siihen sisältyy mieleen, kehoon ja kieleen varastoituneita kokemuksia. Voiko maahanmuuttaja lukea kangaspuiden alla ryömivää opettajaa kuin avointa sanakirjaa? Maahanmuuttajien kohtaamisessa on vaiheita, joissa tarkastellaan eroja. Kuitenkin syvälle luotaavaan kulttuurisesti sensitiiviseen otteeseen kuuluu, että etsitään yhtäläisyyksiä. Vuoropuhelussa niitä voidaan etsiä oppimisympäristöissä kahden tai useamman kulttuurin kohtaajan välillä. Myös maahanmuuttajat voivat oppia toimimaan ryhmässä toistensa tukijoina ja oppimiskeskustelun täydentäjinä. Näin kieli kulttuuri ja käsityö voidaan asettaa palvelemaan maahanmuuttajan kielen ja kulttuurin oppimista. Myös ammatillinen orientaatio kehittyy!

Pitkin alkuopetuskurssia oli pohdittava kielen opettelua luovasti. Persoonapronominien minä, sinä lisäksi demonstratiivipronominit tämä, tuo, se, nämä, nuo, ne kuuluvat opeteltavaan sanastoon. Myös adjektiivit sileä ja karkea, tylsä ja terävä, pyöreä ja kulmikas, kylmäja kuuma; viileä ja haalea tai esimerkiksi verbit kohottaa ja laskea, kiristää ja löystyttää, sitoa ja avata ovat kielen oppimisen eri yhteyksiin liittyviä ilmaisuja. Niiden harjoittelu kuului kiinteästi myös käsityöllisen toiminnan oppimisen sanastoon. Käyttöyhteydeltään laajan sanavaraston kartuttaminen toimii hyvin myös käsityöllistä toimintaa opiskeltaessa.

Käsityöllisen toiminnan oppiminen ja tekeminen altistavat kommunikaatiolle huolimatta oppimisyhteydestä, iästä tai sukupuolesta. Käsityön oppimisen yhteyksissä esille tuleva tekemiseen syventynyt hiljaisuus tai vastaavasti puhumisen vuolaus ovat ääripäitä. Ne osoittavat, että käsitöiden oppiminen ja tekeminen taipuu 
moneksi. Luovan käsityön ja kielen oppimisen yhdistämisessä voidaan ottaa käyttöön näkö- ja kuuloaistin lisäksi kosketus-, tunto- ja hajuaisti. Näin toimien loimme yhdessä maahanmuuttajien ja opettajan välillä apukielen itse.

\section{Tekemisen kielellistäminen}

Kulttuurit muuttuvat. Tulijoiden mukana Suomeen kulkeutunut kulttuuri ei välttämättä ole eikä se maahanmuuttajankaan elämässä näyttäydy samanlaisena kuin mitä se aikanaan oli heidän oman kotimaansa käyttöyhteyksissä. Myöskään oma kulttuurimme ei säily samanlaisena. Länsimainen ajattelu ei ole suosinut tekemisen kielellistämistä. Suomalainen kulttuuri on toiminnan kulttuuria, jossa on mukana liikettä ja suunta. Siinä ei kovin paljon keskustella ja pohdita. (Lappalainen 2005, 182.)

Jokaisessa kulttuurissa on omat uskomuksensa ja arvonsa, joista asenteet ja käyttäytymisen ilmentymät muodostuvat. Ihmiset kasvavat omaan kulttuuriinsa jäsenyyteen, he siirtävät perinteisiä arvojaan, asenteitaan, uskomuksiaan, taitojaan ja tapojaan sukupolvelta toiselle. Arvot määrittelevät sen, mitä pidetään hyväksyttävänä, mitä ei, ja mitä taas arvostetaan muita enemmän. (Padilla 1980.) Kulttuurisesti sensitiivisellä otteella maahanmuuttajan omasta ja maahanmuuton kohdemaan kulttuurista löytyy kulttuuritietoisuuden kannalta yhteistä jaettavaa. Sillä voidaan vastata kulttuurien kohtauttamiseen. Tähän opettajan on luotava ja rakennettava pedagogiikkaa ja pedagogista sisältöosaamista ts. didaktiikkaa.

Maahanmuuttajien kaksikielisyydestä ja sen kehittymisestä on keskusteltu melko vähän. Maahanmuuttaja voi kartuttaa vähän kerrassaan toiminnallista, joustavaa, lisäävää ja osittaista (ToJo-Li-Os-)kaksikielisyyttä ja näin oppia uuden yhteiskunnan kielen. Tätä käden, kielen ja kulttuurin oppimisen yhdistäminen on palvellut. Tätä voi hyödyntää oppilaitoksissa, maahanmuuttajien kohtaamisen hallintokäytännöissä ja erilaisissa ammatillisissa koulutuksissa.

\section{Kä-Ki-Ku-pedagogiikan}

\section{käyttömahdollisuuksia}

- erilaisten maahanmuuttajien alkuopetus-ja jatkokurssien rahoittajat ja maahanmuuttajille kursseja järjestävät oppilaitokset

- yliopistot, opettajankoulutuslaitokset, amma- tilliset opettajakorkeakoulut ja muut korkeakoulut

- yleiskoulu (peruskoulu ja lukio) päiväkodit

- projektit

- kansanopistot, kansalais- ja työväenopistot

- ammatilliset aikuiskoulutuskeskukset

- ammattioppilaitokset ja ammatilliset oppilaitokset

- työvoimahallinto, poliitikot, sosiaalitoimi ja maahanmuuttoasioista vastaavat päättäjät

- opintokeskukset

- TE-keskukset, vastaanottokeskukset

- käsityökeskukset

- asukasyhdistykset ja neuvontajärjestöt

(Lappalainen 2005, 239.)

\section{Oppimistyylin hyödynnettävyys:}

1. Kielen oppimisen ja kulttuurien kohtaa misen ja kohtauttamisen edistäminen

2. Yhteiskunnassa selviytymiseen valmen tautuminen

3. Ammatillinen valmentaminen

4. Ammatillisuus

5. Ammattiosaaminen (Lappalainen 2005).

\section{"Kankaankudontalatinaa"}

Omassa elämässäni on kuulunut toimimista useilla toisistaan poikkeavilla opetusalueilla. Niistä saadut kokemukset ovat edellyttäneet toimintaympäristö- ja koulukohtaista kulttuurien kohtaamista. Työni on ollut luonteeltaan tien raivaamista ja rakentamista. Kohtaamaani pohjoisamerikkalaiset opiskelijat säilyvät lähtemättömänä mielessäni. Olen kiitollinen, että sain kohtasin heidät. Nuoret olivat kiinnostuneita erityisesti kankaankudonnasta ja puikoilla neulonnasta. Kun suunnittelin oppisisältöihin englanninkielistä kankaankudontasanastoon perehdyttämistä, he opettivat minua. He sanoivat: "Kuule, ei tuo ole englantia vaan se on "venäjää." Ymmärsin, ettei ammattitermistön ja "kankaankudontalatinan" osaaminen kulttuurien kohtaamisessa saati kulttuurien kohtauttamisessa paljon auta. Se muistuttaa palaamaan taakse jääneisiin kokemuksiin: Hollon sanoin yksi ainoa otollisessa silmänräpäyksessä singonnut kipinä voi luoda sammumattoman liekin. Oppimispolkuni on ollut pitkä: "Olen unessa useasti sinun kaduillas, koulutie. Ah, enkö mä hautahan asti myös koululainen lie" (Koskenniemi $(1983,145)$. 


\section{Oppimisympäristö kulttuurien kohtauttamisen risteyspaikkana}

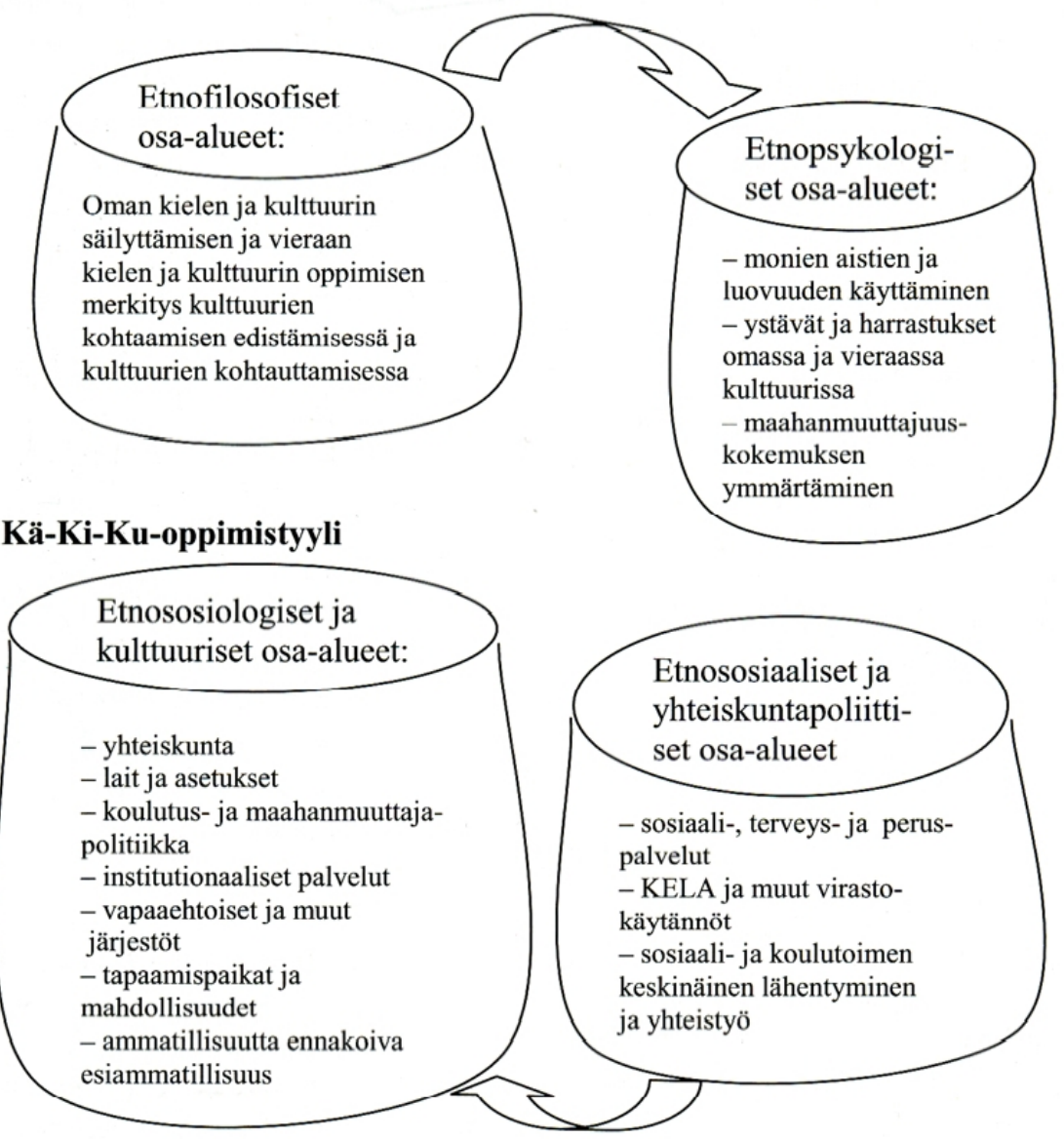

\section{Lähteet}

Alanen, R. (2000). Vygotsky, van Lier ja kielenoppiminen: sosiokulttuurinen viitekehys kielellisen tietoisuuden ja vieraan kielen oppimisen tutkimuksessa. Teoksessa: Kielikoulussa - kieli koulussa. P. Kalaja \& L. Nieminen (toim.) AFinLA. Jyväskylän yliopistopaino, 95-120.

Carneiro, R. (1975)- The Four Fases of Evolution. In: J.J. Honingmann (ed.) Handbook of Social and Cultural Anthropology. Chigago.

Dewey, J. (1910/1960) How We Think. Massachusetts: D.C. Health and Company.

Dewey, J. (1913/1957) Koulu ja yhteiskunta. K. Kajava (suom.) The School and Society. Otava.

Dewey, J. (1934/1987) Art as Experience. In: J. A. Boydston (ed.) J. Dewey: The Later Works,
Vol. 10. Carbondale: Southern Illinois University Press.

Fisher, R. (1990/1995). Teaching Children to Think. Basil Blackwell Ltd. Great Britain by T. J. Press, Padstow, Cornwall. Muuttamaton painos.

Haavikko, P. (1984). Auringonkukkia. Teoksessa: Sillat. Valitut runot. Otava.

Hollo, J. A. (1949). Kasvatuksen teoria. Johdantoa yleiseen kasvatusoppiin. WSOY.

Koskenniemi, V.A. (1983). Runoja. WSOY.

Lappalainen, E-M. (1999) Erilaisten maahanmuuttajaryhmien integroituminen vieraaseen kulttuuriin. Okka-säätiö. Ammattikasvatuksen aikakauskirja 1, 1, 26-31.

Lappalainen, E-M. (2001). Kankaankudonnan 
ja puikoilla neulonnan oppimisen ulottuvuuksia pohjoisamerikkalaisten kokemana Suomessa. Teoksessa: L. Hyvönen \& E. Lindfors (toim.) Tehhään yhesä! Taide- ja taitokasvatuksen tulevaisuus Oulun yliopistossa 23-24.2.2001 pidetyn seminaarin esitelmät. Oulu: Oulun yliopisto. Kasvatustieteiden tiedekunta selosteita ja katsauksia 1/2001, 106-115.

Lappalainen, E-M. (2003a) Finnish weaving, felting, and knitted goods seen and experienced by North Americans: thoughts and Descriptions. In: K. Virta (ed.) Current research on Sloyd Education. Techne Series Research in Sloyd Education and Crafts Science A: 5, 19-36. Digipaino. Turun yliopisto.

Lappalainen, E-M. (2003b) Viewpoints on the Teaching of Different Immigrants into an Ethnic Cultural Orientation. In: K. Virta (ed.) Current research on Sloyd Education. Techne Series Research in Sloyd Education and Crafts Science A: 5, 37-44. Turun yliopisto.

Lappalainen, E-M. (2004a) Building interest in the Study of Language by using Art and Craft Design and Culture. "Working knowledge in a Globalizing World Learning at School - Learning at Work: New Challenges in the Social Organisation of Knowledge" conference $19^{\text {th }}-22^{\text {nd }}$ of August 2004 Oslo: Soermarka, Norway.

Lappalainen, E-M. (2004b) Käsikö käsittää kieltä ja kulttuuria maahanmuuttajien koulutuksessa? Teoksessa: U. Aunola (toim.) Maahanmuuttajat ammattia oppimassa. OPH, 156-162.
Lappalainen, E-M. (2005). Kulttuurisesti sensitiivinen opettajuus; Käden, kielen ja kulttuurin oppimisen yhdistäminen maahanmuuttajien koulutuksen pedagogiikassa ja opettajan kasvupolulla. Oulun yliopisto. Akateeminen väitöskirja, kasvatustieteiden tiedekunta.

van Lier, L. (2004) From imput to affordance: Social-interactive learning from an ecological perspective. In: Sociocultural Theory and Second language Learning. J.P. Lantolf (ed.) Oxford University Press, 246-259.

Lozanov, G. (1978). Suggestology and outlines of suggestopedy. M. Hall-Pozharlieva \& K. Pashmakova. (transl.) New York: Gordon and Breach.

Padilla, A. (1980). The Role of Cultural Awareness and Ethnic Loyalty in Acculturation. In: A. Padilla (ed.) Acculturation Theory, Models and Some New Findings. Boulder, CO: WestviewPress, 48-84.

Peal, E. \& Lambert, W. E. (1962). The relation of bilingualism to intelligence. Psychological Monographs 76, 1-23.

Poikela, E. 1999/2004). Kontekstuaalinen oppiminen; Oppimisen organisoituminen ja vaikuttava koulutus. Akateeminen väitöskirja. Kasvatustieteiden tiedekunta. Acta Electronica Universitatis Tamperensis 339.

Syrjäläinen, E. (1994) Etnografinen opetuksen tutkimus: Kouluetnografia. Teoksessa: L. Syrjälä; S. Ahonen; E. Syrjäläinen \& S. Saari. Laadullisen tutkimuksen työtapoja. Kirjayhtymä, 67-112. 